\title{
PERILAKU GIZI SEIMBANG ANAK SEKOLAH DIPERBAIKI DENGAN EDUKASI GIZI ANAK DAN ORANGTUA
}

\section{Balanced Nutrition Behaviour was Improved by Nutrition Education in Child and Parents}

\author{
Dyah Umiyarni Purnamasari ${ }^{1}$, Endo Dardjito ${ }^{2}$, Kusnandar $^{3}$ \\ ${ }^{1)}$ Program Studi Ilmu Gizi FIKES Unsoed \\ ${ }^{2)}$ Jurusan Kesehatan Masyarakat FIKES Unsoed \\ ${ }^{3)}$ Program Studi Pendidikan Jasmani dan Kesehatan Rekreasi FIKES Unsoed \\ dyahumiyarni@gmail.com
}

\begin{abstract}
The objective of study was to analyze the improving of balanced nutrition behaviour after applying nutritional education through pictorial story media for children and audiovisual media for mothers. The design of this study is a quasi-experimental study. Subjects were 45 students and 45 mothers of Limpakuwus Elementary School, Banyumas Regency. There was increasing of students' knowledge (20.8\%) and maternal nutritional knowledge (15.5\%) after being educated. Different behavior changes occurred significantly (p: $0,000<0.05)$ before and after nutrition education.
\end{abstract}

Keywords: school children, nutrition education, balanced nutrition behaviour

\begin{abstract}
Abstrak
Tujuan pada penelitian ini adalah untuk menganalisis perbaikan perilaku gizi seimbang setelah penerapan edukasi gizi mellaui media cerita bergambar dan audiovisual pada orangtua. Desain penelitian ini adalah Kuasi Eksperimen. Sampel adalah 45 siswa dan 45 ibu pada SD Limpakuwus, Kabupaten Banyumas. Hasil penelitian menunjukkan terdapat peningkatan pengetahuan anak $(20,8 \%)$ dan ibu $(15,5 \%)$ setelah pemberian edukasi. Terdapat perbedaan yang bermakna pada perilaku $(\mathrm{p} 0,000<0,05)$ sebelum dan sesudah edukasi.
\end{abstract}

Kata Kunci: anak sekolah, edukasi gizi, perilaku gizi seimbang

\section{PENDAHULUAN}

Rendahnya status gizi pada anak sekolah merupakan permasalahan gizi yang perlu mendapat perhatian yang serius. Sebanyak $11,2 \%$ anak sekolah di Indonesia mengalami kurus (wasting). Prevalensi kurus pada anak sekolah di Jawa Tengah bahkan melebihi angka nasional yaitu 12,5 \% (Riskesdas, 2013).
Pada penelitian Purnamasari et al. (2016) ditemukan faktor-faktor yang menjadi penyebab kurus pada anak sekolah adalah konsumsi dan pengetahuan gizi anak. Selain itu masih banyaknya orangtua dengan pengetahuan rendah yaitu sebanyak 40,6\%. Status gizi anak sekolah yang rendah harus segera diperbaiki karena berdampak pada kemampuan belajarnya. Penelitian yang dilakukan oleh Puspitasari et al. (2011) 
menunjukkan bahwa anak yang mengalami kurang gizi akan berkurang kemampuan kognitifnya sebesar 22,6 poin. Penelitian yang dilakukan oleh Astyorini (2014) menunjukkan sebanyak $85,7 \%$ anak sekolah dengan status gizi rendah akan mempunyai kemampuan motorik kasar abnormal.

Evaluasi yang dilakukan oleh Analytical and Capacity Development Partnership (2013) yang merupakan lembaga kemitraan pemerintah Indonesia dan Bank Dunia menyebutkan perlunya kerjasama semua pihak dalam memperbaiki gizi dan kesehatan anak sekolah. Dalam taraf keluarga, intervensi terhadap ibu merupakan faktor penting yang harus dilakukan untuk memperbaiki perilaku gizi anak. Intervensi gizi dapat dilakukan dengan menggunakan media promosi kesehatan.

Media promosi kesehatan adalah semua sarana atau upaya untuk menampilkan pesan atau informasi yang ingin disampaikan oleh komunikator, baik itu melalui media cetak, elektronika dan media luar ruang, sehingga sasaran dapat meningkat pengetahuannya yang akhirnya dapat berubah perilaku ke arah positif terhadap kesehatan. (Notoatmodjo, 2012).
Penelitian yang dilakukan oleh Hamida et al. (2012) menunjukkan adanya peningkatan pengetahuan siswa yang berbeda nyata setelah diberi intervensi ceramah dengan media cerita bergambar. Penggunaan media ini akan memudahkan siswa untuk menerima materi penyuluhan yang diberikan. Media lain yang dapat digunakan adalah media elektronik, diantaranya Audiovisual. Keunggulan penyuluhan dengan media ini adalah dapat memberikan realita yang mungkin sulit direkam kembali oleh mata dan pikiran sasaran, serta dapat memicu diskusi mengenai sikap dan perilaku (Lucie, 2005).

\section{Menurut Centers for Disease} Control and Prevention (2011) untuk memperbaiki perilaku gizi anak perlu adanya dukungan dengan pihak keluarga. Keluarga dengan pemahaman gizi yang baik akan meningkatkan perilaku gizi anak. Oleh karena itu intervensi gizi selain dilakukan pada anak juga pada keluarganya untuk menghasilkan perubahan perilaku gizi pada anak sekolah.

Tujuan penelitian ini adalah untuk mengetahui perubahan perilaku gizi anak sekolah setelah anak tersebut mendapat edukasi melalui media cerita bergambar 
dan orangtuanya melalui media audiovisual.

\section{METODE}

\section{Desain, tempat dan waktu}

Desain yang digunakan dalam penelitian ini adalah Kuasi Eksperimen. Tempat penelitian adalah di SD Limpakuwus, Kecamatan Sumbang, Kabupaten Banyumas. Waktu penelitian pada bulan Mei-Juni 2017.

\section{Jumlah dan cara pengambilan subjek}

Subjek dalam penelitian ini adalah siswa dan orangtua. Siswa yang dijadikan sebagai subjek penelitian adalah siswa kelas $\mathrm{V}$, dengan pertimbangan pada jenjang tersebut anak sudah mudah diajak bekerja sama dalam penelitian. Orangtua yang dijadikan subjek penelitian adalah ibu dari siswa tersebut berjumlah 45 orang juga.

\section{Jenis dan Cara Pengumpulan Data}

Jenis data yang dikumpulkan adalah data primer. Pengumpulan data dilakukan dengan teknik wawancara dengan bantuan kuesioner kepada siswa dan orangtua.

\section{Teknik Edukasi Gizi}

Teknik edukasi dilakukan dua tahap. Edukasi pada siswa dengan pemberian media cerita bergambar gizi seimbang, adapun pada orangtua dengan media pemutaran audiovisual gizi seimbang. Pretest perilaku gizi seimbang pada siswa dilakukan sebelum pemberian media anak dan orangtua. Pada saat pemberian media dilakukan pretest dan posttest pengetahuan baik siswa dan orangtua. Posttest perilaku gizi seimbang dilakukan selang 1 minggu setelah dilakukan edukasi gizi.

\section{Pengolahan dan Analisis Data}

Variabel pengetahuan anak, pengetahuan orang tua dan perilaku gizi seimbang anak diolah dengan menjumlahkan skor dari masing-masing pertanyaan berdasar jawaban yang sesuai. Persentase skor diperoleh dengan jumlah skor yang benar dibagi total skor dikali seratus. Kategori pengetahuan dan perilaku dianggap baik apabila skornya lebih dari $80 \%$ (>80\%), sedang $60-80 \%$ dan kurang bila $<60 \%$. Uji statistik digunakan untuk mengetahui perubahan variabel perilaku gizi seimbang. Uji yang digunakan adalah Wilcoxon dengan signifikasi $p$ value $<0,05$.

\section{HASIL DAN PEMBAHASAN}

\section{Karakteristik Siswa Sekolah Dasar}

Proporsi distribusi jenis kelamin siswa hampir sama yaitu laki-laki 53,3\% 
dan perempun sebanyak $46,7 \%$. Ratarata umur siswa adalah 11 tahun 3 bulan, dengan umur termuda adalah 10 tahun dan tertua adalah 14 tahun. Pekerjaan ibu sebagian besar $(95,6 \%)$ adalah ibu rumah tangga, hanya $4,4 \%$ yang bekerja sebagai pedagang. Pendidikan ibu sebagian besar adalah SD $(84,4 \%)$, hanya $11,4 \%$ SMP dan $2,2 \%$ SMA.

\section{Pengetahuan Gizi Seimbang Siswa Sekolah Dasar}

Pengetahuan gizi seimbang siswa sebelum edukasi pemberian media cerita bergambar dan sesudahnya mengalami perubahan. Perubahannya dapat dilihat pada Gambar 1.

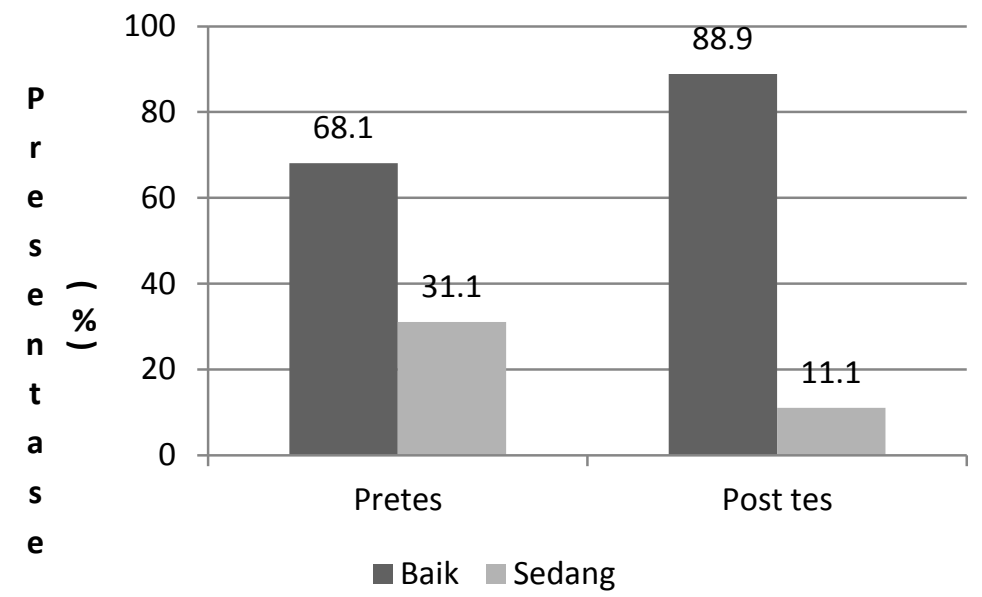

Gambar 1. Perubahan Proporsi Pengetahuan Siswa Berdasar Pengetahuan Gizi Seimbang Sebelum dan Sesudah Pemberian Media Cerita Bergambar

Pemberian media cerita bergambar gizi seimbang terbukti meningkatkan pengetahuan kategori baik pada siswa sebanyak 20,8 \%. Menurut Damayanti (2003) media cerita bergambar untuk anak dapat memperkaya visual dan bisa mendorong anak mencocokkan antara latar belakang dan kejadian dalam cerita. Penelitian yang dilakukan oleh Hamida $e t$ al. (2012) pada siswa SD
Muhammadiyah Kartasura menunjukkan adanya peningkatan pengetahuan siswa setelah diberi ceramah dengan media cerita bergambar. Penggunaan media cerita bergambar akan memudahkan siswa untuk menerima materi penyuluhan yang diberikan. Pada penelitian ini media cerita bergambar dalam bentuk cerita petualangan menemukan sumber-sumber gizi sesuai sepuluh pesan dasar gizi 
seimbang yang dilengkapi dengan ilustrasi yang menarik. Hal ini merangsang minat baca dan keingintahuan anak, dengan demikian pengetahuan gizi yang disampaikan menjadi lebih mudah dapat diterima.

\section{Pengetahuan Gizi Seimbang Orangtua}

Pengetahuan gizi seimbang orangtua sebelum dan sesudah pemberian edukasi Audiovisual seimbang mengalami perubahan. Perubahannya dapat dilihat pada Tabel 2.

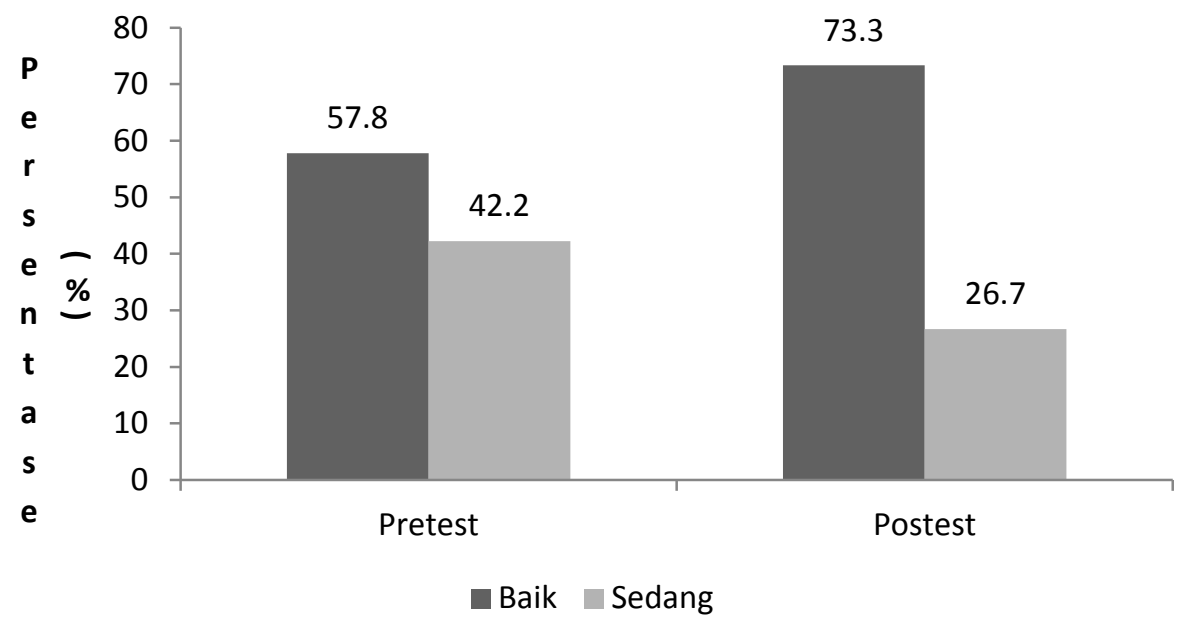

Gambar 2. Perubahan Proporsi Pengetahuan Orangtua Berdasar Pengetahuan Gizi Seimbang Sebelum dan Sesudah Pemberian Media Audiovisual Gizi Seimbang

Pemberian media Audiovisual gizi seimbang pada orangtua terbukti meningkatkan pengetahuan kategori baik pada orangtua sebanyak $15.5 \%$. Penelitian ini sejalan dengan penelitian yang dilakukan oleh Kapti et al. (2013) yang menunjukkan adanya peningkatan pengetahuan, dan sikap ibu setelah diberikan penyuluhan dengan media audiovisual. Sejalan juga dengan penelitian yang dilakukan oleh Wibowo dan Suryani (2013) yang menemukan bahwa penggunaan media Audiovisual dan Buku Saku, keduanya sama-sama dapat meningkatkan pengetahuan gizi ibu secara signifikan.

$$
\text { Menurut Notoatmodjo }
$$
perubahan pengetahuan seseorang dapat dipengaruhi oleh beberapa faktor antara lain sumber pesan, isi pesan dan penerima pesan. Sumber pesan dapat berasal dari seseorang atau sesuatu yang dipercaya oleh penerima pesan. Media Audiovisual yang menyajikan pengetahuan dan pengalaman yang nyata sehari-hari akan lebih mudah diterima 
oleh ibu sehingga cepat meningkatkan pengetahuan dan pemahaman ibu. Pada penelitian ini media Audiovisual berisi sepuluh pesan dasar gizi seimbang disajikan interaktif dan menarik sehingga melengkapi pengalaman dasar responden dan memudahkan penerimaan informasi gizi seimbang yang disampaikan.

\section{Perilaku Gizi Seimbang Anak}

Perilaku gizi seimbang anak sebelum dan sesudah pemberian edukasi komprehensif mengalami perubahan. Perubahannya seperti terlihat pada Gambar 3.

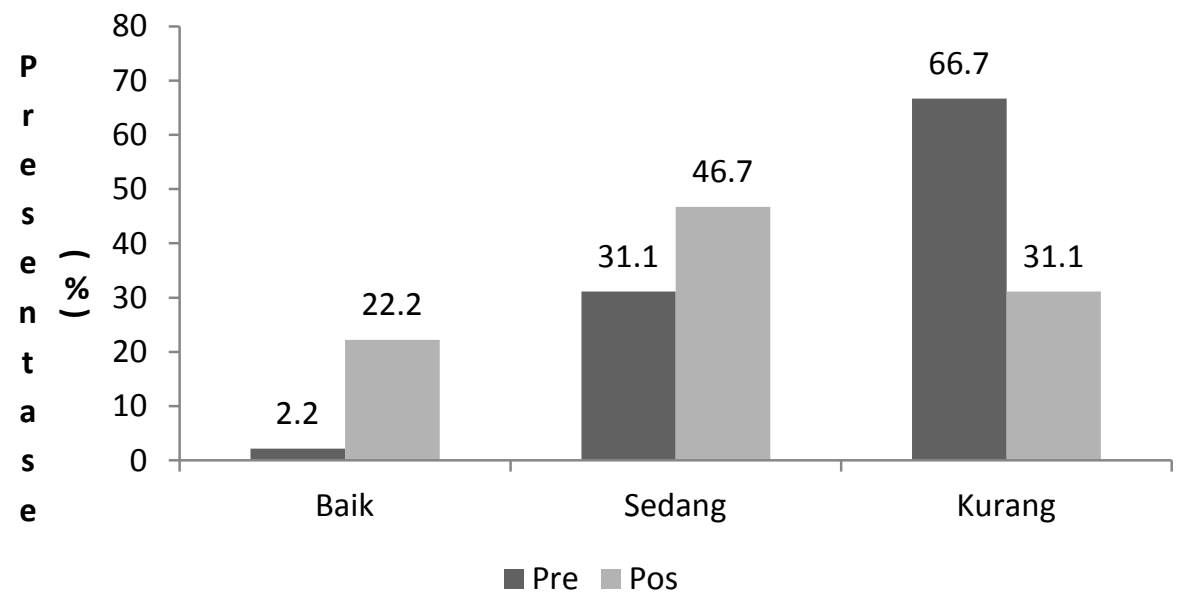

Gambar 3. Perubahan Proporsi Perilaku Gizi Seimbang Siswa Sebelum dan Sesudah Pemberian Edukasi Komprehensif

Pemberian edukasi gizi komprehensif meningkatkan perilaku gizi seimbang siswa kategori baik sebanyak $20 \%$. Berikut adalah proporsi perilaku gizi seimbang kurang baik pada siswa sebelum dan sesudah edukasi komprehensif.

Tabel 1 menunjukkan terjadi penurunan perilaku gizi seimbang siswa yang kurang baik. Penurunan ini didukung oleh penerapan perilaku gizi seimbang yang baik di rumah oleh orangtua. Sebanyak 31,1 \% anak sudah menerapkan makanan yang bervariasi dalam sekali makan. Sebanyak 8,9 \% sudah ada peningkatan konsumsi air putih 8 gelas sehari. Peningkatan yang cukup besar terjadi pada perilaku sarapan. Sebanyak $71,1 \%$ siswa yang tidak biasa sarapan menjadi berkurang 64,7\%. Itu berarti orangtua sudah sadar untuk menyediakan sarapan untuk anakanaknya sebelum sekolah. Menurut Sandercock et al.. (2010) faktor 
lingkungan keluarga seperti pendidikan, pekerjaan, penghasilan orang tua, serta ketersediaan makan pagi di rumah oleh orangtua mempengaruhi perilaku sarapan pada anak sekolah.

Tabel 1. Proporsi Perilaku Gizi Seimbang Kurang Baik Sebelum dan Sesudah Edukasi Komprehensif

\begin{tabular}{llll}
\hline No & Perilaku & $\begin{array}{l}\text { Sebelum } \\
(\%)\end{array}$ & Sesudah (\%) \\
\hline 1 & $\begin{array}{l}\text { Apakah dalam sehari kamu mengkonsumsi pangan yang } \\
\text { terdiri dari seluruh jenis dari kelompok pangan berikut: } \\
\text { makanan pokok, lauk pauk (hewani dan nabati), dan } \\
\text { sayuran atau buah dalam setiap waktu makan? }\end{array}$ & 24,4 \\
\hline 2 & $\begin{array}{l}\text { Apakah setiap hari kamu minum air yang telah dimasak, } \\
\text { sebanyak 8 gelas (setara dengan 2 L)? }\end{array}$ & 42,2 & 33,3 \\
\hline 3 & Apakah kamu sarapan sebelum melakukan aktivitas? & 71,1 & 6,7 \\
\hline 4 & $\begin{array}{l}\text { Apakah setiap hari kamu mencuci tangan dengan sabun di } \\
\text { air yang mengalir sebelum dan sesudah makan? }\end{array}$ & 20 \\
\hline 5 & $\begin{array}{l}\text { Apakah dalam sehari kamu mengkonsumsi makanan } \\
\text { pokok sebanyak 3-4 porsi? }\end{array}$ & 62,2 & 28,9 \\
\hline 6 & $\begin{array}{l}\text { Apakah dalam sehari kamu mengkonsumsi protein hewani } \\
\text { dan nabati masing-masing sebanyak 2-4 porsi? }\end{array}$ & 77,7 & 44,4 \\
\hline 7 & $\begin{array}{l}\text { Apakah dalam sehari kamu mengkonsumsi sayuran } \\
\text { sebanyak 3-4 porsi? }\end{array}$ & 57,7 & 28,9 \\
\hline 8 & $\begin{array}{l}\text { Apakah dalam sehari kamu membatasi konsumsi gula } \\
\text { hanya paling banyak 4 sendok makan gula? }\end{array}$ & 91,1 & 44,4 \\
\hline 9 & $\begin{array}{l}\text { Apakah dalam sehari kamu mengkonsumsi paling banyak } \\
5 \text { sendok makan minyak (setara dengan 5 buah gorengan)? }\end{array}$ & 71,1 & 55,5 \\
\hline 10 & Apakah kamu berjalan kaki/bersepeda menuju ke sekolah? & 35,5 & 28,8 \\
\hline
\end{tabular}

Penelitian yang dilakukan oleh

Sofianita et al. (2015) tentang faktor yang berpengaruh terhadap perilaku sarapan pada anak sekolah menunjukkan pengetahuan gizi, ketersediaan sarapan dan tempat sarapan merupakan faktor yang paling berpengaruh.

Analisis untuk menguji besarnya perilaku gizi seimbang anak sekolah dengan menggunakan uji Wilcoxon.

Tabel 2. Uji Wilcoxon Beda Perilaku Gizi Seimbang Siswa

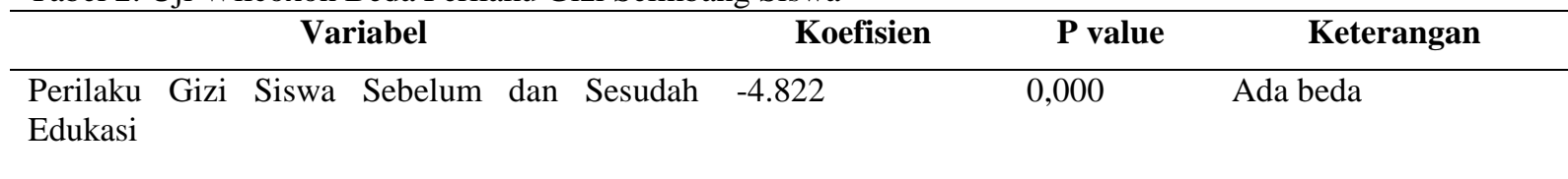


Hasil Uji Wilcoxon p: 0,000 < 0,05 menunjukkan ada perbedaan perilaku gizi seimbang siswa sebelum dan sesudah edukasi gizi komprehensif . Hasil penelitian ini sejalan dengan penelitian yang dilakukan oleh Sartika (2012) yang menunjukkan adanya perbedaan perilaku gizi anak setelah dilakukan berbagai edukasi gizi seperti kartu bergambar, leaflet dan tebak gambar. Penelitian ini juga menekankan peran ibu dalam meningkatkan perilaku gizi anak. Menurut panduan CDC (2011) untuk meningkatkan perilaku makan yang sehat pada anak sekolah harus ada kerjasama dengan orangtua. Kerjasama yang baik akan meningkatkan pemahaman anak, promosi secara konsisten tentang perilaku makan sehat, mendukung, memotivasi serta meningkatkan ketersediaan sumber makanan sehat di rumah.

\section{KESIMPULAN}

Kesimpulan pada penelitian ini adalah adanya perubahan perilaku siswa sekolah setelah edukasi siswa dengan media cerita bergambar dan ibu dengan media audiovisual. Saran dari hasil penelitian ini adalah edukasi gizi bisa dilakukan secara berkelanjutan dengan adanya kerjasama pihak sekolah dalam memantapkan perilaku gizi siswa. Saran untuk penelitian selanjutnya adalah memperbanyak jenis media yang digunakan untuk melakukan edukasi gizi dengan peningkatan frekuensi dan jangka waktu intervensinya.

\section{DAFTAR PUSTAKA}

Astyorini YD. Hubungan Status Gizi terhadap Kemampuan Motorik Kasar Anak Sekolah Dasar. 2014. Jurnal Kesehatan Olahraga 2 (2): 33-39

Center of Disease Control and Prevention. 2011. School Health Guidelines to Promote Healthy Eating and Physical Activity. Morbidity and Mortality Weekly Report 60 (5).

Damayanti. 2003. Media yang Tepat untuk Pembelajaran. Grasindo: Jakarta

Hamida K, Zulaikha S, Mutalazimah. 2012. Penyuluhan Gizi dengan Media Komik untuk Meningkatkan Pengetahuan tentang Keamanan Makanan Jajanan. Kemas 8 (1): 67-73

Kapti RE, Rustina Y, Widyastuti. 2013. Efektifitas Audiovisual sebagai Media Penyuluhan Kesehatan terhadap Peningkatan Pengetahuan dan Sikap Ibu dalam Tatalaksana Balita dengan Diare di Dua Rumah Sakit Kota Malang. Jurnal Ilmu Keperawatan 1(1)

Lucie S. 2005. Teknik Penyuluhan dan Pemberdayaan Masyarakat. Bogor: Penerbit Ghalia Indonesia.

Notoatmodjo S. 2012. Promosi Kesehatan dan Perilaku Kesehatan. Jakarta: Rineka Cipta.

Purnamasari DU, Dardjito E, Kusnandar. 2016. Hubungan Jumlah Anggota Keluarga, Pengetahuan Gizi Ibu dan Tingkat Konsumsi Energi dengan Status Gizi Anak Sekolah. Jurnal Kesmas Indonesia 8(2)

Puspitasari FD, Sudargo T, Gamayanti IL. 2011 Hubungan antara Status Gizi dan Faktor Sosiodemografi dengan Kemampuan 
Kognitif Anak Sekolah Dasar. Gizi Indonesia 34(1):52-60

Riset Kesehatan Dasar 2013. Badan Penelitian dan Pengembangan Departemen Kesehatan Republik Indonesia. http://www.depkes.go.id/resources/downlo $\mathrm{ad} /$ general/Hasil\%20Riskesdas\%202013. pdf [Diakses tanggal 20 Juli 2017]

Sandercock GR, Voss C, Dye L. 2010. Associations between habitual schoolday breakfast consumption, body mass index, physical activity and cardiorespiratory fitness in English schoolchildren. Eur J Clin Nutr 64(10):1086-92.

Sartika RAD. 2012.Penerapan Komunikasi, Informasi dan Edukasi Gizi terhadap Perilaku Sarapan Siswa Sekolah Dasar. Jurnal Kesehatan Masyarakat Nasional $7(2)$

Sofianita NI, Arini FA, Meiyetriani E. 2015. Peran Pengetahuan Gizi dalam Menentukan Kebiasaan Sarapan AnakAnak Sekolah Dasar Negeri di Pondok Labu, Jakarta Selatan. Jurnal Gizi Pangan, 10(1): 57-62

Wibowo S dan Suryani D. Pengaruh Promosi Kesehatan Metode Audiovisual dan Metode Buku Saku terhadap Peningkatan Pengetahuan Penggunaan Monosodium Glutamat (MSG) pada Ibu Rumah Tangga. Kesmas, 7(2). 